\title{
Editorial: Holocene Climate Changes in the Asia-Pacific Region
}

\author{
Liangcheng $\operatorname{Tan}^{1,2,3,4 *}$ and Hai $\mathrm{Xu}{ }^{5 *}$ \\ ${ }^{1}$ State Key Laboratory of Loess and Quaternary Geology, Institute of Earth Environment, Chinese Academy of Sciences, Xi'an, \\ China, ${ }^{2}$ China-Pakistan Joint Research Center on Earth Sciences, CAS-HEC, Islamabad, Pakistan, ${ }^{3}$ Center for Excellence in \\ Quaternary Science and Global Change, Chinese Academy of Sciences, Xi'an, China, ${ }^{4}$ Institute of Global Environmental Change, \\ Xi'an Jiaotong University, Xi'an, China, ${ }^{5}$ Institute of Surface-Earth System Science, Tianjin University, Tianjin, China
}

Keywords: chronology, lake sediment, peat, delta deposit, marginal sea, monsoon, westerly, climate impact

Editorial on the Research Topic

Holocene Climate Changes in the Asia-Pacific Region

As a fast-growing economic region, more than two-thirds of the global population lives in the AsiaPacific region. Climate changes in this region not only affect the livelihood and well-being of inhabitants directly, but also influence the world's sustainable development. For example, a recent stalagmite study from southern Thailand suggests extreme wet conditions during the late 14th century. The extreme precipitation caused extensive floods and destruction of the water management systems in Angkor, Cambodia, resulting in the decline of the Khmer Empire (Tan et al., 2019). A 640 year megadrought in central Asia during the mid-Holocene even delayed the opening of the oasis route for trans-Eurasian cultural exchange (Tan et al., 2020a). Despite the recent progress (e.g., Chen et al., 2015; Zhu et al., 2017; Griffiths et al., 2020; Xu et al., 2019; Xu et al., 2020; Tan et al., 2020a; Tan et al., 2020b), both the patterns and the mechanisms of climate change over different sub-regions in the Asia-Pacific during the Holocene, when human civilization developed, are far from well-known. Therefore, reconstructing these changes are essential on the different timescales and shedding light on the driving mechanisms. It will enable a better understanding of the present climatic conditions and their impacts and future trends, especially in the context of continuous global warming (Xu et al., 2019; Tan et al., 2020b). Research Topics of this contribution include improved chronologic methods and new climatic reconstructions and driving forces of climate change on different timescales during the Holocene, covering a broad region from the western Pacific marginal seas to the Asian inland area (Figure 1). The environmental and social impacts of climate change during the historical and modern times are also discussed in this research topic. This special issue brings together a collection of papers that bridge vital knowledge gaps in the critical areas human-environment interactions in the Holocene.

\section{IMPROVED CHRONOLOGY}

Radiocarbon $\left({ }^{14} \mathrm{C}\right)$ dating method was widely applied in various materials of sediments, including plant fossils, bulk organic matter, and carbonates. However, bulk organic matter, and carbonates may be contaminated by the ${ }^{14} \mathrm{C}$ reservoir effect in water bodies. The ${ }^{14} \mathrm{C}$ reservoir effect may be variable through time (An et al., 2012), which brings significant challenges to establish reliable chronologies for lake and delta sediment records. In this collection, Zhou et al. systematically studies the ${ }^{14} \mathrm{C}$ reservoir ages of the sediments from Lake Bosten in Xinjiang, China. They found the ${ }^{14} \mathrm{C}$ reservoir ages during a dry interval $(1,800$ to $650 \mathrm{BP})$ was 1,170 years older than those during the wet periods (650-100 BP; 2,200-1,800 BP). This results suggested different ${ }^{14} \mathrm{C}$ exchange rates between the dissolved $\mathrm{CO}_{2}$ in lake water and corresponding $\mathrm{CO}_{2}$ in the atmosphere. There is a changing 


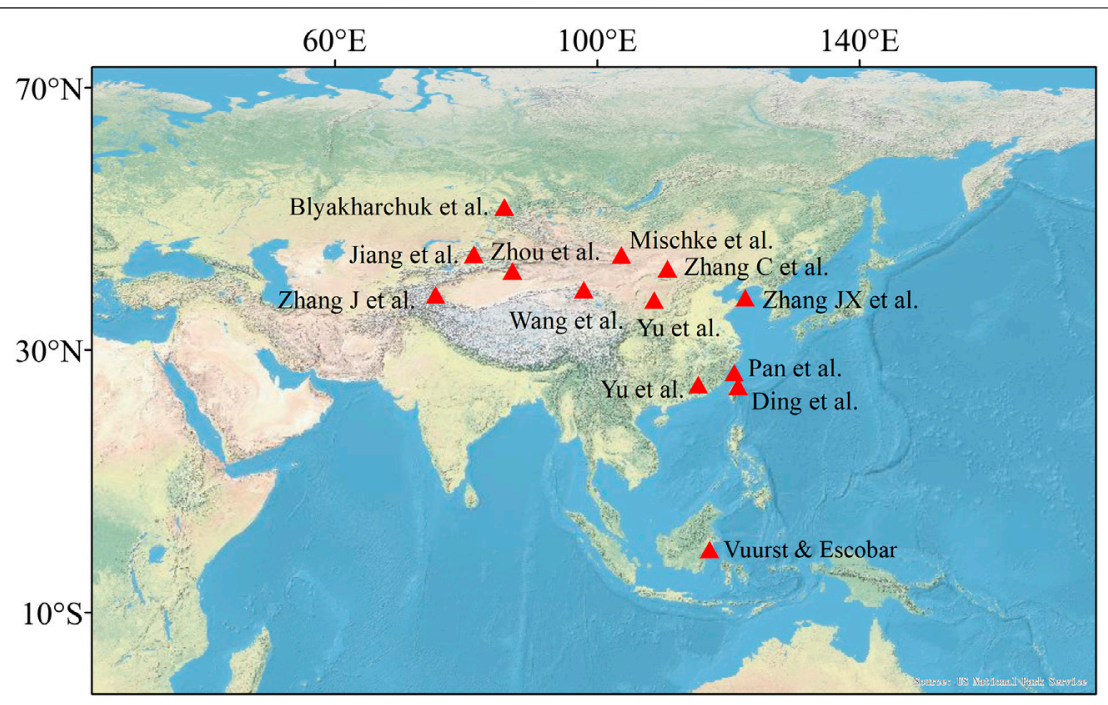

FIGURE 1 | Locations of the study sites included in this volume.

proportion of lake-derived organic matter and detrital organic matter from a catchment during dry and wet conditions, which may affect the resident time for ${ }^{14} \mathrm{C}$ in aquatic environments and can challenge construction of a credible chronology in arid/ semiarid regions. Besides, Blyakharchuk et al. identify a possible old $\mathrm{CO}_{2}$ source from decomposed organic matter from buried, old sediment that may be metabolized by contemporary aquatic algae and submerged plants, may give anomalous old ${ }^{14} \mathrm{C}$ ages. As a result, caution should be exercised on establishing chronologies of sediment cores with just a few ${ }^{14} \mathrm{C}$ dates, even if the ages are in stratigraphic order. A better way is to combine the ${ }^{14} \mathrm{C}$ dating method with ${ }^{210} \mathrm{~Pb},{ }^{137} \mathrm{Cs}$, OSL, and ${ }^{230} \mathrm{Th}$ dating methods to determine the possible variable ${ }^{14} \mathrm{C}$ reservoir ages, as shown by Blyakharchuk et al. and $\mathrm{Xu}$ et al. (2020).

\section{New Insights of Holocene Climate Changes}

Since An et al. (2000) proposed the asynchronous Holocene Optimum in the East Asian monsoon region two decades ago, the timing and patterns of the Holocene precipitation changes in Asia are debated widely (e.g. Zhou et al., 2007; Cai et al., 2010; Chen et al., 2019; Tan et al., 2020b; Xu et al., 2020). Ding et al. synthesized the current hydroclimate records from Taiwan, and suggested that the East Asian Summer Monsoon (EASM) rainfall maximum occurred during the early Holocene. They further suggested the EASM rainfall maximum occurred progressively later, from the early Holocene in southern China to the middle Holocene in northern China, contrast to An et al. (2000). The latitudinal shifts of the westerlies and western Pacific Subtropical High caused by interhemispheric or zonal Pacific temperaturt gradients were employed to explain the asynchronous EASM rainfall changes during the Holocene (Xu et al., 2020). Zhang et al. 's multiproxy studies from Tengger Nuur in the Inner Mongolian Plateau, China, support a middle Holocene precipitation maximum in northern China (Chen et al., 2015). However, the ostracod, gastropod, and charophyte records from Lake Ulaan in Mongolia, northwest of Tengger Nuur, indicated the highest inflows and highest productivity in and around the lake, and wettest climate conditions during the early Holocene (Mischke et al.). Cheng et al. also suggested a southward migration of the monsoon fringe during the Holocene, as illustrated in a transient climate-terrestrial ecosystem model simulation. The discrepancies may reflect chronologic uncertainties of the various records, or potentially varying climate sensitivity of the different proxies. Some proxies may reflect annual and seasonal precipitation changes or effective precipitation changes with storm intensity with non-analogous atmospheric circulations. For example, Tan et al. (2020b) suggested that the earlier wetting of the western Chinese Loess Plateau compared to the eastern sector may reflect increased rainfall associated with a stronger Indian summer monsoon during the early Holocene. In contrast, a well-dated record of $\delta^{13} \mathrm{C}$ for black carbon from sediment core of Sayram Lake in Xinjiang, China reveals persistently wetter conditions during the Holocene (Jiang et al.), which is consistent with other records from eastern central Asia (Chen et al., 2019; Xu et al., 2019). This increase in effective moisture in eastern central Asia is linked to North Atlantic sea surface temperatures and changes in Westerly circulation. Specifically, the Community Earth System Model simulations show gradually southward and strengthened summer westerly jet over central Asia from the early Holocene to late Holocene (Zhou et al., 2007). In turn, Wang et al. further confirmed the out-of-phase relationship of humidity conditions between westerlies-dominated central Asia and monsoon areas over the past century.

Climatic changes in the western Pacific marginal seas are also studied in this collection. Pan et al. reconstructed the Holocene sea surface temperature (SST) and subsurface water temperature (SWT) of the East China Sea using $\mathrm{UK}^{\prime} 37$ and TEX86, respectively. They found the SWT decreased between 6 and 
4 ka with SWT increased in the late Holocene, almost in antiphase with the SST. These results provide new insight into the interaction mechanism among the winter monsoon, precipitation and the Kuroshio Current.

\section{Environmental and Social Impacts of Climate Change}

Li et al. reviewed the global mercury deposition, climate change, and human activities. They found more mercury accumulation during the glacial period and less during the interglacial period. Zhang J. et al. suggested changes in temperature and wind speed may dominate the dust storm's frequency and intensity in northwest China. Global warming may lead to decreased temperature gradients and wind speed. Thus, reducing dust storm frequency and intensity in central Asia in the past century. As a result, less and weaker dust storms are expected under a continuously warming scenario. The social impacts of monsoon precipitation changes are discussed in this collection. Zhang J.X. et al. found close relationships between changes in the Chinese economy and monsoon precipitation for northern China, as reconstructed from northern Yellow Sea sediments. Also, there appears to be an association between the frequency of wars over the past 2000 years and monsoon variability, consistent with Tan et al. (2011) observations. In traditional agriculture societies, low precipitation may lead to

\section{REFERENCES}

An, Z., Colman, S. M., Zhou, W., Li, X., Brown, E. T., Timothy Jull, A. J., et al. (2012). Interplay between the Westerlies and Asian monsoon recorded in Lake Qinghai sediments since 32 ka. Sci. Rep. 2, 619. doi:10.1038/srep00619

An, Z., Porter, S. C., Kutzbach, J. E., Wu, X., Wang, S., Liu, X., et al. (2000). Asynchronous Holocene optimum of the East Asian monsoon. Quat. Sci. Rev. 19, 743-762. doi:10.1016/S0277-3791(99)00031-1

Cai, Y., Tan, L., Cheng, H., An, Z., Edwards, R. L., Kelly, M. J., et al. (2010). The variation of summer monsoon precipitation in central China since the last deglaciation. Earth Planet. Sci. Lett. 291, 21-31. doi:10.1016/j.epsl.2009.12.039

Chen, F., Chen, J., Huang, W., Chen, S., Huang, X., Jin, L., et al. (2019). Westerlies Asia and monsoonal Asia: spatiotemporal differences in climate change and possible mechanisms on decadal to sub-orbital timescales. Earth Sci. Rev. 192, 337-354. doi:10.1016/j.earscirev.2019.03.005

Chen, F., Xu, Q., Chen, J., Birks, H. J. B., Liu, J., Zhang, S., et al. (2015). East Asian summer monsoon precipitation variability since the last deglaciation. Sci. Rep. 5, 11186. doi:10.1038/srep 11186

Griffiths, M. L., Johnson, K. R., Pausata, F. S. R., White, J. C., Henderson, G. M., Wood, C. T., et al. (2020). End of Green Sahara amplified mid- to late Holocene megadroughts in mainland Southeast Asia. Nat. Commun. 11, 4204. doi:10. 1038/s41467-020-17927-6

Hus, K. J. (1998). Sun, climate, hunger, and mass migration. Sci. China Earth Sci. 41, 449-472. doi:10.1007/bf02877737

Tan, L., Cai, Y., An, Z., Edwards, R. L., Cheng, H., Shen, C. C., et al. (2011). Centennial- to decadal-scale monsoon precipitation variability in the semihumid region, northern China during the last 1860 years: records from stalagmites in Huangye Cave. Holocene 21, 287-296. doi:10.1177/0959683610378880

Tan, L., Dong, G., An, Z., Edwards, R. L., Li, H., Li, D., et al. (2020a). Megadrought and cultural exchange along the proto-Silk Road. Sci. Bull. [Epub ahead of print]. doi:10.1016/j.scib.2020.10.011 crop failure, resulting in famine, which may cause uprisings and ultimately wars (Hus, 1998). Currently, there are many countries in Asia that are and will be impacted by climate change in the 21st century. Case-in-point is the effect of climate change and human overuse of resources upon Jakarta, Indonesia, where the government has recently planned to relocate the capital to the island of Borneo. Vuurst and Escobar discussed the possible adverse effects of the relocation. They called for multidisciplinary research in Borneo to determine its ecosystems' status for a comprehensive assessment, before and after urban expansion to better understand Anthropogenic impacts.

\section{AUTHOR CONTRIBUTIONS}

All authors listed have made a substantial, direct, and intellectual contribution to the work and approved it for publication.

\section{FUNDING}

LT and HX acknowledge the supports from National Key Research and Development Program of China (2017YFA0603401) and the Strategic Priority Research Program of Chinese Academy of Sciences (XDB40000000).

Tan, L., Li, Y., Wang, X., Cai, Y., Lin, F., Cheng, H., et al. (2020b). Holocene monsoon change and abrupt events on the western Chinese Loess Plateau as revealed by accurately-dated stalagmites. Geophys. Res. Lett. 47 (21), e2020GL090273. doi:10.1029/2020GL090273

Tan, L., Shen, C. C., Löwemark, L., Chawchai, L., Edwards, R. L., Cai, Y., et al. (2019). Rainfall variations in central Indo-Pacific over the past 2700 year. Proc. Nat. Acad. Sci. U.S.A. 116 (35), 17201-17206. doi:10.1073/pnas. 1903167116

Xu, H., Goldsmith, Y., Lan, J., Tan, L., Wang, X., Zhou, X., et al. (2020). Juxtaposition of western Pacific subtropical high on Asian Summer monsoon shapes subtropical East Asian precipitation. Geophys. Res. Lett. 47, 255-258. doi:10.1029/2019GL084705

Xu, H., Zhou, K., Lan, J., Zhang, G., and Zhou, X. (2019). Arid Central Asia saw mid-Holocene drought. Geology 47, 255-258. doi:10.1130/G45686.1

Zhou, W., Song, S., Burr, G., Jull, A. J. T., Lu, X., Yu, H., et al. (2007). Is there a timetransgressive Holocene optimum in the East Asian monsoon area? Radiocarbon 49 (2), 865-875. doi:10.1017/S0033822200042739

Zhu, Z., Feinberg, J. M., Xie, S., Bourne, M. D., Huang, C., Hu, C., et al. (2017). Holocene ENSO-related cyclic storms recorded by magnetic minerals in speleothems of central China. Proc. Nat. Acad. Sci. U.S.A. 114, 852-857. doi:10.1073/pnas.1610930114

Conflict of Interest: The authors declare that the research was conducted in the absence of any commercial or financial relationships that could be construed as a potential conflict of interest.

Copyright (C) 2021 Tan and Xu. This is an open-access article distributed under the terms of the Creative Commons Attribution License (CC BY). The use, distribution or reproduction in other forums is permitted, provided the original author(s) and the copyright owner(s) are credited and that the original publication in this journal is cited, in accordance with accepted academic practice. No use, distribution or reproduction is permitted which does not comply with these terms. 